\title{
Examining the Relationship of Organizational Intelligence with Innovation Management and Career Advancement in an Organization
}

\author{
Atefeh Oveisi Kahkha*, Abdulwahab Pourghaz, Afsane Marziyeh \\ Department of Educational Sciences, Faculty of Educational Sciences and Psychology, University of Sistan and \\ Baluchestan, Zahedan, Iran \\ Email: w.pourghaz@ped.usb.ac.ir
}

Received 18 March 2015; accepted 13 May 2015; published 10 September 2015

Copyright (C) 2015 by authors and Scientific Research Publishing Inc.

This work is licensed under the Creative Commons Attribution International License (CC BY). http://creativecommons.org/licenses/by/4.0/

c) (7) Open Access

\section{Abstract}

The present study aimed to examine the relationship of organizational intelligence with innovation management and career advancement in an organization. Considering its objective, this was a descriptive-correlational study. The statistical population included all high school managers in Zahedan at the year 2015. The sample contained 52 male managers and 51 female managers whom were selected through applying stratified random sampling method. To collect data, Organizational Intelligence Questionnaire, Innovation Management Inventory and Questionnaire of Career Advancement were used, the validity of which was assessed through applying the standpoint of a number of university professors and their reliability was obtained $0.74,0.76,0.84$, respectively, using Cronbach's alpha coefficient. Results indicated that considering managers' perspectives, the status of organizational intelligence and career advancement were desirable; however, the status of innovation management was moderate. Moreover, organizational intelligence and its components were significantly and positively correlated with innovation management $(\mathrm{r}=$ $0.512, P<0.01$ ), and there was a significant and positive relationship between organizational intelligence and career advancement $(r=0.334, P<0.01)$. Findings demonstrated that components of desire to change, spirit, unity and agreement, application of knowledge, performance pressure were significantly correlated to career advancement. However, components of strategic perspective and common fate were not significantly correlated with career advancement. Additionally, among the components of organizational intelligence, in the first step, application of knowledge and in the second step, desire to change were the best predicators of innovation management (which together could predict $\mathbf{2 8 \%}$ ). Application of knowledge was the only variable which entered the predictive model and predicted $16 \%$ of career advancement. Results of independent

\footnotetext{
${ }^{*}$ Corresponding author.
}

How to cite this paper: Kahkha, A.O., Pourghaz, A. and Marziyeh, A. (2015) Examining the Relationship of Organizational Intelligence with Innovation Management and Career Advancement in an Organization. Journal of Behavioral and Brain Science, 5, 395-404. http://dx.doi.org/10.4236/jbbs.2015.510038 
t-test indicated that no significant difference was found between male and female managers, considering their organizational intelligence, innovation management and career advancement.

\title{
Keywords
}

\author{
Organizational Intelligence, Innovation Management, Career Advancement
}

\section{Introduction}

Nowadays, numerous studies have discussed various types of intelligence. Intelligence mainly refers to the ability to receive, understand, and use signs and symbols and is an abstract ability. These days, intelligence is a prerequisite for many managerial concepts, representing how organizations and organizational thinkers consider the concept of intelligence and its impacts on individuals' performance in an organization. A type of intelligence is organizational intelligence. Organizational intelligence enables individuals to make organizational decisions. Organizational intelligence means having a comprehensive knowledge of all factors affecting an organization and having an in-depth knowledge about all factors including customers, competitors, economic environment, and organizational operations and processes which have strong influences on the quality of managerial decisions in an organization [1]. Excessive accumulation of knowledge is one of the main features of new organizations such that, in the last two decades, increase in the volume of information in organizations and the need to apply this knowledge in organizational decisions lead to the emergence of a phenomenon known as organizational intelligence [2]. Organizational intelligence, which is the outcome of active human intelligence and artificial intelligence, aids an organization to provide related facilities and make important and rational decisions improving the performance and efficiency of the organization. Performance of each individual in various situations indicates his/her insight and knowledge about that particular situation and/or issue. Given the fact that individual's organizational intelligence demonstrates one's awareness and knowledge of factors affecting an organization, therefore, organizational intelligence can be considered as a factor promoting an individual's performance within an organization [3]. In the current era, organizations have figured out that they will not sustain, unless they apply a strategy for their management and organizational intelligence. Moreover, they have to determine the strengths and weaknesses of their organizational intelligence through applying decision-making and planning techniques. To this end, they have to avoid any undue focus on parts of the organization which cannot have any effects on improving the organization and its future [4]. Due to its close relationship with flexibility and production, innovation can be mentioned as another important and critical issue for individuals, organizations, and all together for all communities [5]. Innovation is a process which is accompanied with organizational changes and can be regarded as an impact of high organizational intelligence, since in smart organizations, people easily accept changes and continuously seek for the best possible method for doing tasks and constantly look for methods of improving the spirit of innovation in the organization [6]. Organizational intelligence enables an organization to face today's turbulent and uncertain environments. Generally, innovation in an organization roots in organizational intelligence of that organization, since organizational intelligence indicates the capacity of the organization for being innovative [7].

The importance of organizational intelligence is due to the fact that individual intelligence alone cannot be used to overcome issues ahead; therefore, to overcome the problems, there is a need to develop collective intelligence within an organization as a necessity [8]. The most significant factors playing key roles in human development and progress in all areas are innovation and creativity. That is why innovation is considered as a key factor in the survival of an organization in the current competitive environment [9]. Increasing human life changes in various political, economic, social, and technological aspects enhance the necessity of creating new and innovative ideas, as a result of which issues related to creativity, innovation, changes in paradigms, trends, events, and images in various aspects of life should be taken more seriously into consideration. Drucker believes that any organization requires innovation. Innovation is a key factor leading to organizational growth and enhancing organizational performance. It works as an engine which allows organizations to benefit from continuous performance. In recent decades, with the dominance of the competitive culture in economic, political, social, and organizational environments, innovation is considered as a successful solution, as an integral part of the 
community, and in a more micro-level of organizational environments. Therefore, companies and organizations that wish to develop or maintain their competitive advantage have to be flexible and accept changes. In this period, innovation has become organizations' main foundations [10]. In the current changing circumstances, creativity and innovation are the main conditions for survival and keys to success. The necessity of applying innovation in organizations is such that some scholars assert that lack of innovation and creativity equals to destruction of an organization in long term. The necessity and importance of creativity and innovation in organizations is due to the fact that organizations are at a point in time which is known as knowledge era, post-industrial era, information society era and creativity and innovation era. In this era, organizations prepare themselves to manage rapid changes and adapt themselves to profound worldwide alternations in a way that creativity and innovation are considered as key elements of the survival of the organization [11]. In today's organizational environment, organizations play an important role in career advancement paths systems. Management of career advancement paths, also known as organizational support aiming to develop career advancement paths, refers to programs, processes, and aids which are provided by an organization to promote and protect its employees' success in career advancement paths. Preparing the ground for promoting career advancement is a key factor which activates an organization, because when employees feel that the grounds for their growth and development are provided, they feel satisfied with their jobs and consequently their self-concept and self-esteem increase. This promotes their organizational performance [12].

Considering the fact that organizational intelligence influences innovation as well as employees and managers' job performance, addressing this issue is of great importance and aids organizations to reduce their problems. Recognizing the importance of organizational intelligence and understanding the relationship of organizational intelligence with innovation management and career advancement in an organization are important steps towards organizations' development. Therefore, the present study sought to examine this question: Is organizational intelligence related to innovation management and career advancement of high school managers of Department of Education in Zahedan?

\section{Objectives}

\subsection{Overall Objective}

To determine the relationship of organizational intelligence with innovation management and career advancement.

\subsection{Special Objectives}

1. To determine the status of organizational intelligence, innovation management and career advancement from the perspective of managers.

2. To determine the relationship of organizational intelligence and its components with innovation management.

3. To determine the relationship of organizational intelligence and its components with career advancement.

4. To predict innovation management by organizational intelligence components.

5. To predict career advancement by organizational intelligence components.

6. To compare male and female managers' organizational intelligence, innovation management and career advancement.

\subsection{Research Questions}

1. How are the status of organizational intelligence, innovation management, and career advancement from the perspective of high school managers in Zahedan?

2. Are organizational intelligence and its components significantly correlated with innovation management?

3. Are organizational intelligence and its components significantly correlated with career advancement?

4. Are the components of organizational intelligence able to predict innovation management?

5. Are the components of organizational intelligence able to predict career advancement?

6. Is there any significant difference between male and female managers' with regard to their organizational intelligence, innovation management, and career advancement?

\subsection{Methods}

Given the nature and objectives of the current study, i.e. examining the relationship of organizational intelli- 
gence with innovation management and career advancement in Department of Education in Zahedan, this was a descriptive-correlational study. The statistical population included all high school managers in Zahedan $(\mathrm{N}=$ 141), among whom 72 individuals were male and 69 individuals were female. The sample included 103 individuals, the size of which was determined through applying Krejcie and Morgan Table (1970), among whom 52 individuals were male, 51 managers were female and 80 managers were graduate (B.A. or B.Sc.) and 32 managers were postgraduate (M.A. or M.Sc.) selected through using stratified random sampling methods.

Three questionnaires were used as measurement tools in the current study including Organizational Intelligence Questionnaire (Karl Albrecht, 2003), Innovation Management (Vivienne, 1990) adapted from Moghimi (2002), the validity of which was assessed through applying the standpoint of a number of university professors, and reliability of the questionnaires were calculated through Cronbach's alpha coefficient.

Meanwhile we obtained the ethnical committee approval and informed consent.

The components of organizational intelligence and their Cronbach's alpha coefficient are presented in the following table.

Results of Table 1 show the Cronbach's alpha coefficient for Organizational Intelligence Questionnaire and its components

This questionnaire is scored using a 5-point Likert type scale on which higher score shows desirable status.

Figures of Table 2 indicate the scoring of organizational intelligence questionnaire.

Results of Table 3 show the Cronbach's alpha coefficient for Innovation Management Inventory.

Figures in Table 4 indicate that how innovation management inventory was scored.

Result of Table 5 shows the Cronbach's alpha coefficient for career advancement Questionnaire

Questionnaire of Career Advancement has 8 items and is scored based on a 5-point Likert type scale which is presented in the following Table 6.

Table 1. Reliability of organizational intelligence questionnaire and its components.

\begin{tabular}{ccc}
\hline Component & Number of questions & Reliability (Cronbach alpha) \\
\hline Strategic perspective & $1-7$ & 0.79 \\
Common fate & $8-14$ & 0.79 \\
Desire to change & $15-21$ & 0.69 \\
Spirit & $22-28$ & 0.81 \\
Unity and agreement & $29-35$ & 0.77 \\
Application of knowledge & $26-42$ & 0.86 \\
Performance pressure & $43-49$ & 0.81 \\
Organizational intelligence & 49 & 0.84 \\
\hline
\end{tabular}

Table 2. Scoring organizational intelligence questionnaire.

\begin{tabular}{ccccc}
\hline Totally disagree & Disagree & Neither agree nor disagree & Agree & Totally agree \\
\hline 1 & 2 & 3 & 4 & 5 \\
\hline
\end{tabular}

Table 3. The Cronbach’s alpha coefficient for Innovation Re Management Inventory

\begin{tabular}{cc}
\hline Number of questions & Reliability (Cronbach alpha) \\
\hline 5 & 0.66 \\
\hline
\end{tabular}

Table 4. Scoring innovation management inventory.

\begin{tabular}{cccc}
\hline Yes & Somehow & No \\
\hline 3 & 2 & 1 \\
\hline
\end{tabular}


Table 5. Reliability of questionnaire of career advancement.

\begin{tabular}{cc}
\hline Number of questions & Reliability (Cronbach alpha) \\
\hline 8 & 0.74 \\
\hline
\end{tabular}

Table 6. Scoring questionnaire of career advancement.

\begin{tabular}{ccccc}
\hline Very important & Important & Neither important nor unimportant & Unimportant & Very unimportant \\
\hline 5 & 4 & 3 & 2 & 1 \\
\hline
\end{tabular}

Note: In all three questionnaires higher score shows desirable status.

\subsection{Data Analysis}

To analyze the obtain data and test the hypotheses, both descriptive and inferential statistics were applied, including mean, standard deviation, one-sample t-test, Pearson correlation coefficient, regression analysis, and independent t-test. It should be noted that all these analytical analyses were conducted using SPSS.

\section{Results}

\subsection{Research Questions}

1. How are the status of organizational intelligence, innovation management, and career advancement from the perspective of managers of high schools in Zahedan?

To answer this questions, one-sample t-test was used, the results of which is presented in the following table.

Results demonstrated in Table 7 indicate that mean and standard deviation of managers' organizational intelligence are 171.30 and 27.38, respectively. This mean is greater than the test value, i.e. 149, therefore, this difference is statistically significant at the $99 \%$ confidence level $(t=8.265, \mathrm{p}<0.01)$. It can be concluded that the status of managers' organizational intelligence is desirable.

Results demonstrate that mean and standard deviation of managers' innovation management are 10.25 and 2.09, respectively. This mean is slightly greater than the test value, i.e. 10, therefore, this difference is not statistically significant $(\mathrm{t}=1.226, \mathrm{p}>0.05)$. It can be concluded that the status of managers' innovation management is moderate.

Results show that mean and standard deviation of managers' career advancement are 32.86 and 4.47, respectively. This mean is greater than the test value, i.e. 24 , therefore, this difference is statistically significant $(\mathrm{t}=$ $20.105, p<0.01$ ). It can be concluded that the status of managers' career advancement is desirable.

2. Are organizational intelligence and its components significantly correlated with innovation management?

To answer this question, Pearson correlation coefficient was used, the results of which are presented in Table 8.

Results demonstrated in Table 8 indicate that there is a significant and positive relationship $(\mathrm{r}=0.512)$ between organizational intelligence and innovation management at 99\% confidence level. Moreover, components of common fate $(r=0.254)$, desire to change $(r=0.461)$, spirit $(r=0.443)$, unity and agreement $(r=0.349)$, application of knowledge $(r=0.508)$, and job performance $(r=0.428)$ are significantly correlated with managers' innovation management at the $99 \%$ confidence level. However, strategic perspective is significantly and directly related to managers' innovation management at the 95\% confidence level $(r=0.247)$. It can be concluded that promoting organizational intelligence and its components improves managers' innovation management.

3. Are organizational intelligence and its components significantly correlated with career advancement?

To answer this question, Pearson correlation coefficient was used, the results of which are presented in Table 9 .

Results demonstrated in Table 9 indicate that there is a significant and positive relationship between organizational intelligence and career advancement at $99 \%$ confidence level $(r=0.334)$. Moreover, components of spirit $(r=0.268)$, unity and agreement $(r=0.256)$, application of knowledge $(r=0.399)$, and job performance $(r=$ 0.270 ) are significantly correlated with managers' career advancement at the $99 \%$ confidence level and desire to change $(r=0.227)$ is significantly and positively related to managers' career advancement at the $95 \%$ confidence level. However, components of strategic perspective $(r=0.178)$ and common fate $(r=0.143)$ have no 
Table 7. One-sample t-test conducted to examine the status of organizational intelligence, innovation management, and career advancement of managers.

\begin{tabular}{ccccccccc}
\hline Variable & $\mathrm{N}$ & Mean & $\mathrm{SD}$ & Test value & $\mathrm{df}$ & $\mathrm{t}$ & Sig. \\
\hline Organizational intelligence & 103 & 171.30 & 27.38 & 149 & 102 & 8.265 & 0.000 \\
Innovation management & 103 & 10.25 & 2.09 & 10 & 102 & 1.226 & 0.223 \\
Career advancement & 103 & 32.86 & 4.47 & 24 & 102 & 20.105 & 0.000 \\
\hline
\end{tabular}

Table 8. Results of Pearson correlation coefficient of organizational intelligence and its components with innovation management.

\begin{tabular}{cccccccccc}
\hline Variable & \multicolumn{2}{c}{$\begin{array}{c}\text { Organizational } \\
\text { intelligence }\end{array}$} & $\begin{array}{c}\text { Strategic } \\
\text { perspective }\end{array}$ & $\begin{array}{c}\text { Common } \\
\text { fate }\end{array}$ & $\begin{array}{c}\text { Desire to } \\
\text { change }\end{array}$ & Spirit & $\begin{array}{c}\text { Unity and } \\
\text { agreement }\end{array}$ & $\begin{array}{c}\text { Application of } \\
\text { knowledge } \\
\text { performance }\end{array}$ \\
\hline $\begin{array}{c}\text { Innovation } \\
\text { management }\end{array}$ & $\mathrm{R}$ & 0.512 & 0.247 & 0.254 & 0.461 & 0.443 & 0.349 & 0.508 \\
\hline
\end{tabular}

$\mathrm{N}=103$.

Table 9. Results of Pearson correlation coefficient of organizational intelligence and its components with career advancement.

\begin{tabular}{ccccccccccc}
\hline Variable & $\begin{array}{c}\text { Organizational } \\
\text { intelligence }\end{array}$ & $\begin{array}{c}\text { Strategic } \\
\text { perspective }\end{array}$ & $\begin{array}{c}\text { Common } \\
\text { fate }\end{array}$ & $\begin{array}{c}\text { Desire to } \\
\text { change }\end{array}$ & Spirit & $\begin{array}{c}\text { Unity and } \\
\text { agreement }\end{array}$ & $\begin{array}{c}\text { Application of } \\
\text { knowledge }\end{array}$ & $\begin{array}{c}\text { Job } \\
\text { performance }\end{array}$ \\
\hline $\begin{array}{c}\text { Innovation } \\
\text { management }\end{array}$ & $\mathrm{R}$ & 0.334 & 0.178 & 0.143 & 0.227 & 0.268 & 0.256 & 0.399 \\
& Sig. & 0.001 & 0.072 & 0.149 & 0.021 & 0.006 & 0.009 & 0.000 \\
\hline
\end{tabular}

$\mathrm{N}=103$.

significant relationship with career advancement.

4. Are the components of organizational intelligence able to predict innovation management?

To answer this question, stepwise regression analysis was used, the results of which are presented in Table 10.

To examine the amount of contribution of organizational intelligence components in explaining changes related to innovation management, stepwise regression analysis was used. Results of Table 10 indicate that, in the first step, application of knowledge and in the second step, desire to change were entered into the equation. As demonstrated in the above table, in the first step, component of knowledge alone explains $25 \%$ of the variance of innovation management. However, in the second step, component of application of knowledge together with desire to change explain $28.6 \%$ of the variance of innovation management.

5. Are the components of organizational intelligence able to predict career advancement?

To answer this question, stepwise regression analysis was used, the results of which are presented in Table 11.

Results of stepwise regression analysis in Table 11 indicate that among all components of organizational intelligence, only application of knowledge was entered into the equation. This component alone explains $15.1 \%$ of the variance of career advancement. However, other components are not able to predict this variable in a significant way.

6. Is there any significant difference between male and female managers' with regard to their organizational intelligence, innovation management, and career advancement?

The results of t-test in Table 12 indicate that there is no significant difference between male and female managers considering their organizational intelligence $(t=1.772, \mathrm{p}>0.05)$, innovation management $(\mathrm{t}=1.531$, $\mathrm{p}>0.05)$ and career advancement $(\mathrm{t}=1.777, \mathrm{p}>0.05)$.

\subsection{Discussions and Conclusions}

Interpreting and discussing the results with respect to each research question is presented in the following section. 
Table 10. Results of regression analysis conducted to predict innovation management based on components of organizational intelligence.

\begin{tabular}{cccccccccc}
\hline Pattern & $\begin{array}{c}\text { Variables which } \\
\text { entered into the model }\end{array}$ & $\mathrm{R}$ & $\mathrm{R}^{2}$ & $\mathrm{ADJ} . \mathrm{R}^{2}$ & $\mathrm{SE}$ & $\mathrm{B}$ & $\beta$ & $\mathrm{F}$ & Sig. \\
\hline $\begin{array}{c}\text { Stepwise } \\
\text { regression }\end{array}$ & $\begin{array}{c}\text { Application of } \\
\text { knowledge }\end{array}$ & 0.508 & 0.258 & 0.250 & 1.81 & 0.194 & 0.508 & 35.08 & 0.000 \\
& Desire to change & 0.548 & 0.300 & 0.286 & 1.77 & 0.247 & 0.614 & 21.430 & 0.000 \\
\hline
\end{tabular}

Table 11. Results of regression analysis conducted to predict career advancement based on components of organizational intelligence.

\begin{tabular}{cccccccccc}
\hline Pattern & $\begin{array}{c}\text { Variables which entered } \\
\text { into the model }\end{array}$ & $\mathrm{R}$ & $\mathrm{R}^{2}$ & ADJ.R ${ }^{2}$ & $\mathrm{SE}$ & $\mathrm{B}$ & $\beta$ & $\mathrm{F}$ \\
$\begin{array}{c}\text { Stepwise } \\
\text { regression }\end{array}$ & Application of knowledge & 0.399 & 0.159 & 0.151 & 4.12 & 0.327 & 0.399 & 19.12 & 0.000 \\
\hline
\end{tabular}

Table 12. Examining the difference between male and female managers with regard to the variables under study.

\begin{tabular}{cccccccc}
\hline Variable & Gender & $\mathrm{N}$ & Mean & $\mathrm{SD}$ & $\mathrm{df}$ & $\mathrm{t}$ & Sig. \\
\hline Organizational & Female & 51 & 176.08 & 26.17 & & & \\
intelligence & Male & 52 & 166.62 & 27.98 & 101 & 1.772 & 0.079 \\
\multirow{2}{*}{ Innovation management } & Female & 51 & 10.57 & 2.03 & & & \\
& Male & 52 & 9.94 & 2.12 & 101 & 1.531 & 0.129 \\
Career advancement & Female & 51 & 33.65 & 4.25 & & & \\
& Male & 52 & 32.1 & 4.6 & 101 & 1.777 & 0.079 \\
\hline
\end{tabular}

1. How are the status of organizational intelligence, innovation management, and career advancement from the perspective of managers of high schools in Zahedan?

Results of one-sample t-test demonstrated in Table 7 indicated that considering managers' perspectives, organizational intelligence mean was higher than the moderate level; therefore, it can be inferred that with regard to managers' perspectives, the status of organizational intelligence was desirable. This finding is in line with the results of Lefter, Prejmerean, and Vasilache (2008) [13] and Bob Al-Havaieji et al. (2010) [14]. However, this result is not consistent with the results of the study of Faghihi and Ja'fari (2009) [15], indicating that the status of organizational intelligence of the Management and Planning Organization of Iran is lower than the moderate level.

Results of one-sample t-test showed that from the perspective of managers, innovation management mean was moderate. This indicated that the status of innovation management from managers' perspectives was not very desirable. This finding is not in line with the results of Fathizadeh et al. (2011) [16].

Moreover, results indicated that from managers' perspectives, career advancement mean was higher than the moderate level; therefore, it can be concluded that career advancement, from the perspective of managers, had a desirable status. This finding is consistent with the results of Hatam et al. (2009) [17].

2. Are organizational intelligence and its components significantly correlated with innovation management?

Results presented in Table 8 proved that organizational intelligence and its components were significantly and positively correlated with innovation management. This finding is in line with the results of Yaghoubi and Talebizadeh (2012) [18], Fallah Shams et al. (2009) [19], Kafetsios (2004) [20], Carlisle and McMillan (2008) [21], and Whit (2008) [22].

3. Are organizational intelligence and its components significantly correlated with career advancement?

Results demonstrated in Table 9 indicated that there was a significant and positive relationship between organizational intelligence and career advancement. Moreover, components of desire to change, spirit, unity and agreement, application of knowledge, and job performance were significantly correlated with managers' career advancement. However, components of strategic perspective and common fate had no significant relationship 
with career advancement. This finding is in line with the results of Simic (2005) [23], Macgilchrist and Jreed (2004) [24], Lefter, Prejmerean, and Vasilache (2008) [13], Ferdousi et al. (2012) [25], Shams Morkani et al. (2014) [26].

4. Are the components of organizational intelligence able to predict innovation management?

Results of stepwise regression analysis (Table 10) indicated that, in the first step, application of knowledge and in the second step, desire to change were entered into the equation. In the first step, component of knowledge alone explained $25 \%$ of the variance of innovation management. However, in the second step, component of application of knowledge together with desire to change promoted the correlation coefficient by 0.548 and predicted $28.6 \%$ of the variance of innovation management.

5. Are the components of organizational intelligence able to predict career advancement?

Results of stepwise regression analysis indicated that among all components of organizational intelligence, only application of knowledge was entered into the equation. This component alone explained $15.1 \%$ of the variance of career advancement. However, other components were not able to predict this variable in a significant way.

6. Is there any significant difference between male and female managers’ with regard to their organizational intelligence, innovation management, and career advancement?

Results of independent t-test (Table 12) demonstrated that there was no significant difference between male and female managers considering their organizational intelligence, innovation management, and career advancement.

Considering the obtained results, it can be concluded that in today's competitive world, organizations which employ talented and skilled human resources will be successful. Through controlling internal and external factors, these organizations can benefit from their human resources' talent and intelligence to achieve their organizational goals. Organizations that have high levels of organizational intelligence have considerable advantages, compared to others, in understanding organizational problems, perceiving and acquiring knowledge, organizational innovation, career advancement, and individual and organizational performance. Improving and promoting organizational intelligence can create more coordination between plans and programs, improve decisionmaking and innovation, improve job performance, and enhance the long-term prospects of an organization. Given the definition of organizational intelligence, it can be argued that to take advantage of human resources, measuring organizational intelligence and attempting to improve and promote it in an organization are of great importance. To perform jobs better and to improve organizational performance, having innovative managers who have high levels of organizational intelligence is essential. In this regard, managers who have higher organizational intelligence can achieve higher degrees of success. Accordingly, paying attention to organizational intelligence as a key concept affecting management and attempting to improve it in organizations can aid managers to achieve significant benefits in individual, group, and organizational level through providing appropriate grounds for improving organizational performance, organizational innovation, and organizational learning. Therefore, managers need organizational intelligence to promote organizational goals, achieve them, and improve their performance. In general, it can be stated that if the conditions for promotion of organizational intelligence are provided, organizations’ innovation and career advancement will improve.

\section{Recommendations}

\section{Recommendations with Regard to the Obtained Results}

1. Considering the obtained results which indicate that organizational intelligence is significantly correlated with innovation management and career advancement, organizational intelligence should be considered by managers. This means that they should evaluate, periodically investigate, and reassess every single dimension of organizational intelligence in their organization. This promotes organizational intelligence subsystems which are required by the organization in order to become an organization with high organizational intelligence.

2. Encouraging and supporting employees when they do their jobs well and providing suitable and regular feedback facilities for employees and providing a fair and performance-based payment system to improve the performance of organizations are highly recommended.

3. Managers should pay great attention to factors influencing organizational innovation mentioned in this article to solve organizational problems and challenges. Moreover, analyzing and assessing factors affecting formation of innovation process in an organization should be considered. Additionally, removing barriers and 
strengthening the opportunities and factors affecting creativity and innovation in an organization should be regarded.

4. Innovative recommendations and creative solutions provided to improve organizational performance should be encouraged.

5. Employees should be propelled by managers to improve their creativity and innovation.

6. Among all components of organizational intelligence, application of knowledge is the only variable which is able to predict innovation management and career advancement. Therefore, providing grounds for application of knowledge is highly recommended. When the grounds for application of knowledge are not provided, eventually the spirit of creativity and innovation in the organization will drop and organizational performance will stagnate.

\section{References}

[1] Abzari, M., Etebarian, A. and Sattari Qhafarokhi, M. (2006) Organizational Intelligence and Avoiding Collective Stupidity. Journal of Organizational Knowledge Management, 22, 11-14.

[2] Halal, W.E. (2006) Organizational Intelligence: What Is It, and How Can Managers Use It to Improve Performance? Knowledge Management Review, 1, 20-25.

[3] Beikzadeh, J., Alaei, M.B. and Asgandari, S. (2010) Examine the Relationship of Managers' Organizational Intelligence with Their Performance in Governmental Organizations in Eastern Azarbaijan. Research Management, 3, 143163.

[4] Akgun, A.E., Byrne, J. and Keskin, H. (2007) Organizational Intelligence: A Structuration View. http://www.emeraldinsight.com/00935-4814.htm

[5] Runco, R.F. (2004) Perception of Learning Culture, Concerns about the Innovation, and Their Influence on Use of an On-Going Innovation in the Malaysian Public Sector. Doctoral Dissertation, University of Georgia, Athens.

[6] Weijermars, R. (2011) Developing Organizational IQ: A Corporate Necessity. In: Weijermars, R., Ed., Building Corporate IQ-Moving the Energy Business from Smart to Genius, Springer, London, 3-20. http://dx.doi.org/10.1007/978-0-85729-679-5 1

[7] Glynn, M.A. (1996) Innovate Genius: A Frame Work for Relating Individuals and Organization Intelligences to Innovation Academy of Management. Journal of Applied Psychology, 86, 326-336.

[8] Maries, I. and Scarlat, E. (2011) Enhancing the Computational Collective Intelligence within Communities of Practice Using Trust and Reputation Models. In: Nguyen, N.T., Ed., Transactions on Computational Collective Intelligence III, Springer-Verlag, Berlin Heidelberg, 74-95. http://dx.doi.org/10.1007/978-3-642-19968-4_4

[9] Kerr, B. and Gagliardi, C. (2003) Measuring Creativity in Research and Practice. In: Lopez, S.J. and Snyder, C.R., Eds., Positive Psychological Assessment: A Handbook of Models and Measures, American Psychological Association, Washington DC, 155-169. http://dx.doi.org/10.1037/10612-010

[10] Salajeghe, S. and Nazeri, M. (2008) The Role of Tacit Knowledge Management in Creativity and Innovation. The 1st National Conference Studying Creativity, Engineering and Innovation Management, International Olympic Hotel Conference Center, Tehran, November 2008, 35-52.

[11] Tavalaee, R.A. and Alirezaee, A.T. (2008) Ways to Strengthen Innovation and Development in the Organization. Journal of Management and Human Resources in the Petroleum Industry, 3, 67-96.

[12] Zarvandi, M. (2005) Factors and Barriers to Career Advancement of Women in the Military. Defense and Cultural Studies of Women, 1, 117-121.

[13] Lefter, V., Prejmerean, M. and Vasilache, S. (2008) The Dimension of Organizational Intelligence in Romanian Companies-A Human Capital Perspective. Academy of Economic Studies, Bucharest.

[14] Bob Al-Havaieji, F., Ghazi, J. and Ali Allahian, M.S. (2010) Measuring Organizational Intelligence of Staff of Libraries of Ferdowsi University of Mashhad and Astan Quds Razavi. Library and Information Science Journal, 13, 33-39.

[15] Faghihi, A.R. and Ja'fari, A.R. (2009) The Amount of Components of Organizational Intelligence in the Management and Planning Organization of Iran. Journal of Education-Curriculum Development, 23, 45-66.

[16] Fathizadeh, A.R., Paktinat, E. and Shahba, M.J. (2008) Investigate the Level of Creativity and Innovation in Three Governmental Offices Including Department of Education and Training, Agriculture, and Health Care Services in Sirjan and Provide a Model to Increase the Level of Creativity and Innovation in These Organizations. Management Journal, 8, 79-94.

[17] Hatam, N., Heydari, A., Keshtkaran, V. and Heidari Arjlou, P. (2011) Evaluation of Career Advancement Paths of Staff of Shiraz University of Medical Sciences Headquarters. Health Information Management, 8, 815-823. 
[18] Yaghoubi, N.M. and Talebizadeh, M. (2012) Examine the Relationship between Organizational Intelligence and Organizational Innovation in Organization of Economic Affairs and Finance in Kerman. The 2nd National Conference on Student Entrepreneurship, 25 October 2012, 75-79.

[19] Fallah Shams, M.F., Bodaghi Khajenobar, H. and Delnavaz Asghari, B. (2009) Examining the Relationship of Organizational Intelligence with Creativity and Innovation of Staff of Islamic Azad University-Central Tehran Branch. Beyond Management, 6, 149-166.

[20] Kafetsios, K. (2004) Attachment and Organizational Intelligence Abilities across the Life Course Personality and Individual Differences. Journal of Applied Psychology, 86, 326-336.

[21] Carlisle, Y. and McMillan, E. (2006) Innovation in Organizations from a Complex Adaptive Systems Perspective. Emergence: Complexity and Organization, 8, 2-9.

[22] Whit, Ch. (2008) Operational Techniques of Creative Thinking. Advanced Management, 20, 38-49.

[23] Simic, I. (2005) Organizational Learning as a Component of Organizational Intelligence. Information and Marketing Aspects of the Economically Development of the Balkan Countries. http://unwe.acad.bg/repec/sources/5c2005.pdf

[24] Macgilchrist, B.K. and Jreed, M. (2004) The Intelligent School. London: Paul Chapman Publishing. Journal of Applied Psychology, 86, 326-336.

[25] Ferdousi, M.H., Ghare, M.A. and Marashian, F.S. (2012) Relationship of Organizational Intelligence and Its Components with Job Performance of Managers of Physical Education and Sports Board in Ahvaz. Applied Research in Sport Management and Life Sciences, 1, 73-80.

[26] Shams Morkani, Gh.R., Mashaiekhi, M. and Soleimani, S. (2014) Determining the Role of Organizational Intelligence to Improve Organizational Performance. Educational Psychology Quarterly, 31, 165-189. 